\title{
Turkish Pre-service History Teachers' Self-efficacy Beliefs and Motivations on the Teaching Profession
}

\author{
Aslı Avcı Akçalı \\ Department of Social Studies Education, Dokuz Eylul University, Turkey
}

Copyright $(2017$ by authors, all rights reserved. Authors agree that this article remains permanently open access under the terms of the Creative Commons Attribution License 4.0 International License

\begin{abstract}
This study aims to identify the self-efficacy beliefs and motivations of Turkish pre-service history teachers, with respect to "the teaching profession in general", as well as "the history teaching profession specifically". With a descriptive aim, is the study will be based survey research. The research uses an explanatory mixed method research design based on both quantitative and qualitative approaches. The participants of this study were 40 pre-service senior grade history teachers from two teacher training institutions in Turkey. The data were collected through a self-efficacy questionnaire form and interviews that were carried out during the spring semester of the 2015-2016 academic year. The results showed that the majority of the pre-service history teachers had generally high self-efficacy beliefs on both "generic teacher competencies" and "subject-specific competencies for history teachers" and high motivational perceptions. However, the participants' self-efficacy beliefs and motivation for the history teaching profession specifically were shown to be higher than their self-efficacy beliefs and motivation for the teaching profession in general. Furthermore, when the data were analyzed in terms of the relationship between self-efficacy beliefs and motivations, it was identified that there is a relationship between the two to a certain extent.
\end{abstract}

Keywords Pre-service History Teacher, Self-efficacy, Motivation, Teaching Profession, History Teaching Profession

\section{Introduction}

The opportunities that education can bring may be crucial for students in adapting and meeting the needs of changing and transforming world. Thus, the teacher is one of the key factors when it comes to enabling students to meet the requirements of the current educational systems. Students can acquire the necessary knowledge and skills easily via teachers who possess adequate professional knowledge, skills and attitude. Teachers should be trained in this direction during the in-service period of their teacher training programs. According to the Lisbon Council of the European Union, teacher education programs that are responsible for preparing teachers and school leaders for the teaching profession would need to be of high quality, stay relevant to needs and be based on a well-balanced combination of solid academic research and extensive practical experience. One of the objectives of the Council's Education \& Training Work Program for 2010 was "improving education and training for teachers and trainers". This objective highlighted the "importance of attracting and retaining well-qualified and motivated people to the teaching profession, of identifying the skills that teachers require to meet the changing needs of society, of providing conditions to support teachers through initial and in-service training, and of attracting recruits to teaching and training who have professional experience in other fields" [1].

Well-qualified and motivated teachers have an undeniable importance in providing efficient educational outcomes [2-4]. Besides this, the teachers' perception about their own efficiency and motivations towards the profession is another issue worth evaluating about. This research aims to identify the self-efficacy beliefs and motivations that pre-service history teachers hold towards the teaching profession in general and the history teaching profession specifically, as well as the relationship between the two. Firstly, it will be relevant to provide some conceptual knowledge about the key terms "self-efficacy" and "motivation". These terms will be used in this study within the context of the teaching profession. Related literature will also be reviewed in a later section.

Bandura's [5] self-efficacy theory defined "perceived self-efficacy" as "people's beliefs about their capabilities to produce designated levels of performance that exercise influence over events that affect their lives". Self-efficacy beliefs are able to influence the way people feel, think, behave and motivate, through its diverse effects that are based on cognitive, motivational, affective and selection 
processes. Motivation is one of the key concepts of this theory. According to Ryen and Deci [6], "motivation" means "to be moved to do something" and a person who feels no impetus or inspiration to act is thus characterized as unmotivated, while someone who is energized or activated towards an end is considered motivated. The type of motivation may be different depending on its origin. According to most of the referenced categorization identified in the 1990s, motivation may be intrinsic, extrinsic or altruistic, though there is no theoretical consensus on this topic [7].

Motivation, discussed in terms of self-efficacy, refers to an individual's judgment of his or her capabilities to perform certain actions [8]. According to Bandura's theory, there is a direct relationship between the self-efficacy beliefs and motivations of individuals. This is because the strength of one's conviction in his or her own effectiveness is likely to affect the likelihood of one trying to cope with a given situation. The stronger the perceived self-efficacy, the more active the efforts would likely be [9].

When the concept of self-efficacy is used in the context of the teaching profession, it refers to the beliefs that teachers hold about their own perceived capability in undertaking certain teaching tasks [10]. High self-efficacy belief is important as it is related to the positive educational outcomes for both students and teachers [11]. Pre-service education is the key process in aiding candidate teachers gain efficiency in realizing their teaching tasks. At the same time, students in these institutions should be motivated on the teaching profession. This is also because motivational factors play an important role in ensuring that candidate teachers actually enter and stay on the teaching profession $[12,13]$. However, recent studies have suggested that there are certain issues regarding the recruitment and retention of young teachers [14-17]. This may be related to various factors, some of which are associated with the structure of the processes that these teachers have experienced at teacher training institutions, with regards to self-efficacy and motivation. As these processes place great importance on the self-efficacy beliefs and motivations of pre-service teachers, the subject has attracted the attention of many educational researchers.

There have been some studies that examined the level of self-efficacy beliefs of pre-service teachers in teacher training institutions, with respect to teaching skills [18-22].Other research studies have also identified variables such as gender, class, academic success, training program, length of training and country, as well as how these variables may affect the perception that the pre-service teachers hold about their self-efficacy [23-29]. Researchers have also identified the motivations that pre-service teachers hold towards the teaching profession and the factors influencing these motivations [30-36]. In these studies, the factors reducing and increasing the motivation of pre-service teachers were examined. Some of these studies mentioned the effect of gender, grade, program type and the environment that the teachers lived in, while others evaluated the type of motivational factors. Furthermore, there are also research studies propounding that there is a positive correlation between self-efficacy and motivation of pre-service teachers [37-42].

In the studies mentioned above, the self-efficacy beliefs and motivations of pre-service teachers teaching different subjects like chemistry, science, social sciences, English, Turkish, physical education were also examined. In contrast to these research studies, this study aims to identify the self-efficacy beliefs and motivations of pre-service history teachers on the teaching profession. In addition, this study differs from the other studies in its approach to the subject. In the context of the subject area teaching, self-efficacy consists of two facets. Teachers should be efficient in terms of knowledge and skills both for the teaching profession in general as well as for their own specific subject areas. Similarly, these two facets should also be considered when we evaluate motivation. The motivation of pre-service teachers towards the teaching profession in general and their motivation for subject specific teaching may differ. In other words, the factors unique to each subject area may influence the motivation of each teacher. Hence, this research aims to identify the self-efficacy beliefs and motivations of pre-service history teachers in terms of teaching profession in general (TPG) and the history teaching profession specifically (HTPS). It also seeks to explore the relationship between self-efficacy beliefs and motivations, by taking these two facets into account.

\subsection{Generic Teacher Competencies and Subject-specific Competencies for History Teachers in Turkey}

Examining the self-efficacy beliefs of pre-service teachers requires the identification of a set of criteria which will include the different components of efficacy in the context of the teaching profession. In this research, the self-efficacy beliefs of pre-service history teachers were examined according to a standardized competency list (generic teacher competencies and subject-specific competencies for history teachers) as determined by the Turkish Ministry of National Education (TMNE).

In Turkey, apart from the activities for reconstructing primary and secondary education and curriculum development, generic and subject-specific teacher competencies were identified by TMNE in the 2000s. The aim was to increase "the quality of teaching profession by identifying generic and subject-specific competencies and then by equipping teachers and candidate teachers with these competencies by means of pre-service and in-service training programs". These competencies were applied to the setting of teacher training policies, selection of newly assigned teachers, preparation of pre-service teacher training programs for higher education institutions, in-service training of teachers, evaluation of teacher performance, as well as the achievement, personal and 
professional development of teachers [43].

The teacher competencies were identified by a commission determined by MNEGDTT(Ministry of National Education General Directorate of Teacher Training). This commission first studied the resources related to the necessary competencies for the teaching profession in Turkey and other countries, before defining the first draft for the list of competencies. Academicians, administrators, teachers, students, related institutions and organizations were then consulted for their opinions and suggestions [44].Through surveys, observations and interviews, the list of competencies was developed and pilot studies were carried out. Based on these studies, the list of generic competencies for the teaching profession as well as subject-specific competencies were determined.

Generic teacher competencies consist of 6 main competencies, which include 31 sub-competencies. The main competencies are:

A. Personal and professional values-professional development,

B. Knowing the student,

C. Learning and teaching process,

D. Monitoring and evaluation of learning and development,

E. School, family and society relationships,

F. Knowledge of curriculum and content [45].

Subject-specific competencies for teachers were designed by the commission, following the generic competencies. The subject-specific competencies for history teachers were completed in 2011 [46, 47]. It consists of 17 sub-competencies under 3 main competencies as follows:

A. Content knowledge

B. Knowledge of field education

C. Attitudes and values [48].

As seen from the above, for history teachers, competency in the history teaching profession would require one to be efficient in both generic teacher competencies and subject-specific competencies. In this study, the self-efficacy beliefs of pre-service history teachers were examined in this context. The list of 31 sub-competencies under the generic teacher competencies and the 17 sub-competencies under the subject-specific competencies for history teachers were used to identify the pre-service senior history teachers' self-efficacy beliefs on TPG and HTPS. The self-efficacy beliefs of the participants on the TPG and HTPS were identified through a questionnaire for which they rated themselves on each of these sub-competencies. In addition, they were also asked about their motivations on the teaching profession and the history teaching profession separately. The relationship between self-efficacy beliefs and motivation was later examined by taking these two components into account.

\section{Method}

The research aims to identify the perceptions of the pre-service history teachers about their self-efficacy and motivation related with the TPG and HTPS and hence a survey type research was used. Survey research is used to identify the perceptions and evaluations of a specific group of people and collect information from some of them in order to gain insight into what the entire group does or thinks [49,50]. In the research, both qualitative and quantitative approaches were taken and hence a mixed method research design was applied. In this design, with the aim of providing a comprehensive analysis of the research problem, "the researcher collects qualitative and quantitative forms of data at the same time during the study and then integrates the information in the interpretation of the overall results"[51]. As the collection and analysis of quantitative data was followed by the collection and analysis of qualitative data, the design was explanatory mixed method research design [52]. In the research, qualitative data were used to explain and interpret the findings of the quantitative data.

In this context, the sub-questions of this study include:

1. What are the self-efficacy beliefs of pre-service history teachers on the generic teacher competencies and subject-specific competencies for history teachers?

2. How strong are the motivations held by pre-service history teachers on TPG and HTPS?

3. What are the factors that affect the motivations of pre-service history teachers on TPG and HTPS?

4. Is there a relationship between the self-efficacy beliefs and motivations of pre-service history teachers on TPG and HTPS?

\subsection{Participants}

This research was performed during the spring semester of the 2015-2016 academic year. In the study, participants were pre-service history teachers of two educational faculties in the west of Turkey. This is due to the impetus of reaching a sufficient number of participants and providing data diversity. The criterion sampling method [53, 54], which is one of the purposeful sampling methods, was used in the selection of participants. Based on this method, people, events, objects or cases who/which meet the pre-defined qualities would then be selected to answer the research question [55].In this research, the first criterion was the grade of the participants. As the processes experienced in teacher training programs are effective on the pre-service teachers' self-efficacy beliefs [56-59], and motivation towards teaching profession $[60,61]$, the senior pre-service history teachers who were closer to graduation were selected as participants.

The other criterion for the selection of participants was GPA. Due to the possibility of its influence on self-efficacy 
beliefs and motivations towards the profession, the GPA of the pre-service history teachers was identified and a balanced distribution of candidates was strived for as much as possible during the selection process. In these two faculties, the GPA was on a 4 point scale. The three group of GPA scores were defined by the researcher as $0-1,3$; $1,4-2,6 ; 2,7-4.00$. It was not possible to select equal number of students from each category but the attention was paid such that the selected students were not overly representing any one of these groups and that students from each group were included as much as possible. 19 senior pre-service history teachers from one of the faculties and 21 from the other were selected as participants after they were asked if they would like volunteer to participate in the questionnaire and interview. It was important for the participants to be willing to volunteer their time as answering the questionnaire and interview took 40 minutes on average. $40 \%(n=16)$ of the participants were male and $60 \%(n=24)$ were female (this is due to the fact that the number of female students was higher than male students for both classes). The participants were between the ages of 21 and 25 .

\subsection{Data Collection Tools and Data Analysis}

In this study, one of the two data collection tools was the self-efficacy questionnaire form. This form consisted of 48 close-ended questions which were based on the sub-competencies of generic teacher competencies and subject-specific competencies for history teachers. These sub-competencies formed the items of the close ended self-efficacy questionnaire (as shown in Table 1 and 2). This is to ensure that these two reports included a comprehensive list of the necessary teacher qualifications and various components of efficacy for the history teaching profession in Turkey. These competencies were designed by field experts and pilot studies were already carried out by General Directorate of Teacher Training though the reliability rate of the instrument was not declared directly in the report. Through the questionnaire, participants were asked whether they had perceived themselves as sufficiently adequate, partially adequate or inadequate for each of these competencies. The frequency and percentage distributions of the answers were calculated and displayed in tables. Chi-square analysis was also performed to present the effect of gender on the self-efficacy beliefs and motivation levels of the participants and the results were given in the tables.

In addition, all of the participants were interviewed on their motivational perception on TPG and HTPS. The interviewing method is a widely used method in qualitative researches [62, 63]. It allows researchers to acquire knowledge about the opinions of individuals on various subjects and the potential reasons for their opinions [64]. Participants were asked two close-ended questions on their motivational perceptions on the TPG and HTPS and four open-ended questions about the factors that affected their motivations. They were asked the following questions during the in the interview:

1. What is your motivation on TPG? (low/moderate/high)

2. What is your motivation on HTPS?

(low/moderate/high)

3. What are the factors that motivate you on TPG?

4. What are the factors that motivate you on HTPS?

5. What are the factors that demotivate you on TPG?

6. What are the factors that demotivate you on HTPS?

Their motivations on TPG and HTPS were examined in different questions so as to examine the effects of unique characteristics or any opinions related to their subject area. Questions in the interview form were examined by 3 experts for validity analysis. The content analysis method was used for the analysis of the answers of open-ended questions. The data were described systematically and clearly; concepts were recognized and then organized to specify the themes [65]. The data were then coded according to these themes and presented in tables. Significant statements of the participants were also cited to exemplify their opinions.

\section{Findings}

\subsection{Self-efficacy Beliefs of Pre-service History Teachers}

The first sub-question of the research aimed to identify the self-efficacy beliefs of pre-service history teachers on generic teacher competencies and subject-specific competencies for history teachers. The frequency and percentage distribution of the participants' answers regarding generic teacher competencies and the P-values for Chi-square analysis on gender variable were illustrated in Table 1. 
Table 1. The Frequency and Percentage Distribution of Pre-service History Teachers' Self-efficacy Beliefs Based on Generic Teacher Competencies and P-values for Chi-Square Analysis on Gender Variable

\begin{tabular}{|c|c|c|c|c|c|c|c|c|}
\hline & \multirow{2}{*}{ Main and Sub-competencies } & \multicolumn{2}{|c|}{ Sufficiently Adequate } & \multicolumn{2}{|c|}{ Partially Adequate } & \multicolumn{2}{|c|}{ Inadequate } & \multirow{2}{*}{ P-value } \\
\hline & & $\mathrm{f}$ & $\%$ & $\mathrm{f}$ & $\%$ & $\mathrm{f}$ & $\%$ & \\
\hline \multirow{8}{*}{$\begin{array}{l}\text { Personal and Professional } \\
\text { Values- Professional } \\
\text { Development }\end{array}$} & Valuing, understanding and respecting the students & 29 & 72.5 & 10 & 25 & 1 & 2.5 & .66 \\
\hline & Believing that students can learn and achieve & 25 & 62.5 & 15 & 37.5 & - & - & .58 \\
\hline & Attaching importance to national and global values & 29 & 72.5 & 10 & 25 & 1 & 2.5 & .61 \\
\hline & Making self-evaluation & 23 & 57.5 & 17 & 42.5 & - & - & .70 \\
\hline & Ensuring personal development & 21 & 52.5 & 14 & 35 & 5 & 12.5 & .19 \\
\hline & Following and making contribution to professional developments & 9 & 22.5 & 26 & 65 & 5 & 12.5 & .45 \\
\hline & Making contribution to improve and develop the school & 11 & 27.5 & 19 & 47.5 & 10 & 25 & .41 \\
\hline & Following professional laws and realizing tasks and responsibilities & 17 & 42.5 & 19 & 47.5 & 4 & 10 & .46 \\
\hline \multirow{4}{*}{ Knowing the Student } & Knowing the developmental characteristics of students & 24 & 60 & 16 & 40 & - & - & .81 \\
\hline & Considering interests and needs of students & 28 & 70 & 12 & 30 & - & - & .87 \\
\hline & Valuing the student & 34 & 85 & 5 & 12.5 & 1 & 2.5 & .40 \\
\hline & Guiding the student & 24 & 60 & 12 & 30 & 4 & 10 & .27 \\
\hline \multirow{7}{*}{ Teaching and Learning Process } & Planning the lesson & 20 & 50 & 19 & 47.5 & 1 & 2.5 & .18 \\
\hline & Preparation of materials & 15 & 37.5 & 21 & 52.5 & 4 & 10 & .10 \\
\hline & Organizing learning environments & 16 & 40 & 19 & 47.5 & 5 & 12.5 & .94 \\
\hline & Organizing extra-curricular activities & 15 & 37.5 & 20 & 50 & 5 & 12.5 & .43 \\
\hline & Diversifying education by taking the individual differences into account & 22 & 55 & 12 & 30 & 6 & 15 & .88 \\
\hline & Time management & 16 & 40 & 21 & 52.5 & 3 & 7.5 & .93 \\
\hline & Behavior management & 22 & 55 & 16 & 40 & 2 & 5 & .43 \\
\hline \multirow{4}{*}{$\begin{array}{l}\text { Monitoring and Evaluation of } \\
\text { Learning and Development }\end{array}$} & Identifying testing and assessment methods and techniques & 17 & 42.5 & 20 & 50 & 3 & 7.5 & .08 \\
\hline & Testing student learning by using different testing techniques & 10 & 25 & 19 & 47.5 & 11 & 27.5 & .44 \\
\hline & $\begin{array}{l}\text { Data analysis and interpretation, providing feedback on student learning and } \\
\text { development }\end{array}$ & 16 & 40 & 21 & 52.5 & 3 & 7.5 & .52 \\
\hline & Reviewing the teaching-learning process according to results & 18 & 45 & 17 & 42.5 & 5 & 12.5 & .50 \\
\hline \multirow{5}{*}{$\begin{array}{l}\text { School, Family and Society } \\
\text { Relationships }\end{array}$} & Knowing the environment & 25 & 62.5 & 13 & 32.5 & 2 & 5 & .46 \\
\hline & Making use of environmental opportunities & 22 & 55 & 14 & 35 & 4 & 10 & .06 \\
\hline & Making the school a culture center & 13 & 32.5 & 20 & 50 & 7 & 17.5 & .09 \\
\hline & Knowing the families and impartiality in relationships with families & 22 & 55 & 12 & 30 & 6 & 15 & .20 \\
\hline & Ensuring family involvement and cooperation & 15 & 37.5 & 19 & 47.5 & 6 & 15 & .49 \\
\hline \multirow{3}{*}{$\begin{array}{l}\text { Knowledge of Curriculum and } \\
\text { Content }\end{array}$} & Knowledge of objectives and principles of Turkish national education & 15 & 37.5 & 20 & 50 & 5 & 12.5 & .31 \\
\hline & Knowledge of subject-specific curriculum and practice skills & 15 & 37.5 & 19 & 47.5 & 6 & 15 & .23 \\
\hline & Monitoring-evaluation and development of subject-specific curriculum & 14 & 35 & 20 & 50 & 6 & 15 & .49 \\
\hline
\end{tabular}


As seen in the Table 1, the pre-service history teachers generally felt themselves to be sufficiently adequate (in 16 sub-competencies) or partially adequate (in 15 sub-competencies) on the sub-competencies for generic teacher competencies. The percentage of the participants that felt themselves inadequate was fairly low. Moreover, according to the Chi-square analysis, self-efficacy beliefs of the participants on generic teacher competencies did not show any significant difference in terms of gender variable. P-value was greater than conventionally accepted significance value of .05 for all items of the questionnaire and the hypothesis of "there was no significant difference between genders in terms of self-efficacy beliefs on generic teacher competencies" was confirmed.

For the first main competency, the majority of the participants felt sufficiently adequate in the sub-competencies that were related to "personal-professional values", "self-evaluation" and "personal development". However, the majority of these participants also perceived themselves as partially adequate regarding "professional development". For the other main competency of "knowing the student", a majority of the participants showed that they had felt themselves sufficiently adequate for each of the sub-competencies. On the contrary, all of participants responded that they felt themselves partially adequate in all sub-competencies with regards to "knowledge of curriculum and its content". In other main competency of "teaching and learning process", the pre-service history teachers generally identified themselves as partially adequate. Moreover, in the sub-competency of "planning the lesson" the percentages of participants perceiving themselves as sufficiently adequate and partially adequate were very close in figures. "Monitoring and evaluation of learning and development" is the other main competency for which the majority of participants felt themselves partially adequate for most of the sub-competencies. In addition, for the sub-competency of "reviewing the teaching-learning process according to results", the two ratings (partially adequate and sufficiently adequate) were very close in percentages. There was also a remarkably high percentage of participants $(27.5 \%)$ who felt that they were inadequate with regards to the testing of the student's learning by using different testing techniques. In the aspect of "school, family and society relations", most of the participants felt themselves sufficiently adequate in majority of the sub-competencies.

The participants perceived themselves sufficiently adequate in the competencies related to the necessary values, desire for personal development, knowing and valuing the student. They might perceive themselves as intrinsically so due to their professional preference or that they were able to have attained these competencies during in-service period. Yet, the items on which the majority of the participants perceived themselves as partially adequate were concentrated in professional development, teaching and learning process, evaluation of learning and knowledge of curriculum. This might be related to the lack of training mainly, because these competencies require a special professional training that can be attained in specific courses in the teacher training institutions. They had not been trained specifically to be sufficiently adequate in professional development and, teaching-learning-evaluation activities in their teacher training institution. Moreover, the other reason that they might have perceived themselves as partially adequate in these competencies might be the lack of practical knowledge and activities. If they had not received the opportunity to practice and apply theoretical professional knowledge, it would be difficult for them to feel adequate in the competencies related to the teaching and learning process and the evaluation of learning and development. Besides this, the findings showed that they did not feel that they possess sufficient knowledge and practice opportunities related to the curriculums.

The findings related to the self-efficacy beliefs of the participants in terms of the subject-specific competencies for history teachers and P-values for Chi-square analysis on gender variable were displayed in Table 2. 


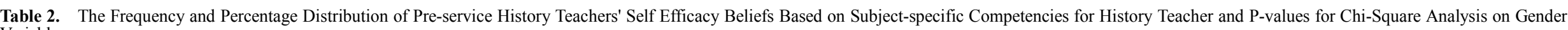
Variable

\begin{tabular}{|c|c|c|c|c|c|c|c|c|}
\hline \multicolumn{2}{|r|}{ Main and Sub-competencies } & \multicolumn{2}{|c|}{ Sufficiently Adequate } & \multicolumn{2}{|c|}{$\begin{array}{l}\text { Partially } \\
\text { Adequate }\end{array}$} & \multicolumn{2}{|c|}{ Inadequate } & \multirow{2}{*}{ P-value } \\
\hline & & f & $\%$ & f & $\%$ & $\mathrm{f}$ & $\%$ & \\
\hline \multirow{3}{*}{$\begin{array}{l}\text { Content } \\
\text { Knowledge }\end{array}$} & Using historical methodology & 22 & 55 & 17 & 42.5 & 1 & 2.5 & .48 \\
\hline & $\begin{array}{c}\text { Evaluating the role of events, facts/phenomena and people related with } \\
\text { Turkish history }\end{array}$ & 27 & 67.5 & 9 & 22.5 & 4 & 10 & .07 \\
\hline & $\begin{array}{l}\text { Evaluating the role of events, facts/phenomena and people related with } \\
\text { world history }\end{array}$ & 27 & 67.5 & 13 & 32.5 & - & - & .58 \\
\hline \multirow{11}{*}{$\begin{array}{l}\text { Knowledge of } \\
\text { Field Education }\end{array}$} & Analyzing the aims and benefits of history education & 27 & 67.5 & 12 & 30 & 1 & 2.5 & .88 \\
\hline & Evaluating the development of history education in the world and Turkey & 23 & 57.5 & 15 & 37.5 & 2 & 5 & .99 \\
\hline & Analyzing the psycho-social basis of adolescents' historical understanding & 24 & 60 & 12 & 30 & 4 & 10 & .96 \\
\hline & Practicing curriculums & 16 & 40 & 20 & 50 & 4 & 10 & .75 \\
\hline & Developing and using materials & 14 & 35 & 21 & 52.5 & 5 & 12.5 & .29 \\
\hline & Applying mutual decisions by participating coterie meetings & 20 & 50 & 14 & 35 & 6 & 15 & .26 \\
\hline & Making practices by using first and second hand resources & 18 & 45 & 20 & 50 & 2 & 5 & .94 \\
\hline & Applying reading and writing strategies in history course & 25 & 62.5 & 12 & 30 & 3 & 7.5 & .45 \\
\hline & Relating history course with other courses and environment & 19 & 47.5 & 19 & 47.5 & 2 & 5 & .40 \\
\hline & Practicing active learning methods and techniques & 18 & 45 & 19 & 47.5 & 3 & 7.5 & .52 \\
\hline & Following and evaluating the development of history learning & 25 & 62.5 & 15 & 37.5 & - & - & .25 \\
\hline \multirow{3}{*}{$\begin{array}{l}\text { Attitudes and } \\
\text { Values }\end{array}$} & $\begin{array}{c}\text { Having general attitudes and values related with history and history } \\
\text { education }\end{array}$ & 27 & 67.5 & 11 & 27.5 & 2 & 5 & .27 \\
\hline & Having attitudes and values related with covering history courses & 28 & 70 & 12 & 30 & - & - & .65 \\
\hline & $\begin{array}{l}\text { Having attitudes and values related with cultural heritage and historical } \\
\text { artifacts }\end{array}$ & 23 & 57.5 & 16 & 40 & 1 & 2.5 & .46 \\
\hline
\end{tabular}


As seen in Table 2, majority of the pre-service history teachers felt themselves sufficiently adequate in most of the sub-competencies (except 4 sub-competencies) for the subject-specific competencies. This is a relatively high percentage when compared to the results for generic teacher competencies. Moreover, similar with the results of the Chi-square analysis related to the generic teacher competencies, self-efficacy beliefs of the participants on subject-specific competencies did not show any significant difference in terms of gender variable. Because the P-value was greater than .05 for all items of the questionnaire, it might be interpreted that there was no significant difference between the male and female participants' self-efficacy beliefs on subject-specific competencies.

When the details were examined, it was seen that majority of the participants perceived themselves sufficiently adequate on the competencies related with content knowledge. In these two departments, as in many other history education departments in the country, most of the lecturers are experts on history but not on history education. Hence, they might be focused on training pre-service teachers on historical content knowledge. This might be the reason for the higher self-efficacy beliefs in the participants on historical content knowledge. Moreover, their intrinsically positive attitudes towards history and the history teaching as well as the attainments they received in their department in this manner might increase the self-efficacy beliefs on subject-specific competencies related with the values and attitudes.

However, the sub-competencies for which the participants perceived themselves as partially adequate was significant for the main competency of "knowledge of field education". Majority of the participants had felt that they were partially adequate in three sub-competencies ("developing and using materials", "making practices by using first and second hand resources", "practicing active learning methods and techniques"). Moreover, the number of the participants feeling sufficiently adequate and the number of those who felt partially adequate were equal in one of the sub-competencies ("relating history course with other courses and environment") and these numbers were also close when comparing to results in one other sub-competency ("practicing active learning methods and techniques"). Pedagogy courses in these teacher training institutions are generally taught by lecturers from the departments of educational sciences and not by field educators. Hence, the teacher candidates have to bridge the gap between pedagogy and content knowledge on their own. Courses at the teacher training institutions might not be sufficiently taught in a way that integrates pedagogy education and content knowledge. This might lead to the participants' beliefs of inadequacy on knowledge of field education. Moreover, the number and the quality of the courses might be the reason of lower self-efficacy beliefs. "Practicing curriculums" is the other sub-competency of subject-specific competencies on which majority of the participants perceived themselves partially adequate. The participants had also similar self-efficacy perceptions related with the curriculums in generic teacher competencies. This showed that they were not sufficiently informed about the curriculums.

Although their self-efficacy beliefs were generally high, the sub-competencies on which the participants perceived themselves partially adequate showed that generic teacher competencies and subject-specific competencies were not sufficiently taken into account and utilized in history teacher training departments. Courses and practical opportunities were not sufficient or qualified enough to ensure prospective teachers feel themselves sufficiently adequate on some of the competencies.

\subsection{Motivations of Pre-service History Teachers on TPG and HTPS}

For the second sub-question of this research that explores the participants' motivations, they were asked about their level of motivation on TPG and HTPS. The results about the level of motivation and effect of gender on participants' perception were described in Table 3.

Table 3. Pre-service History Teachers' Level of Motivation about TPG and HTPS and P-values for Chi-Square Analysis on Gender Variable

\begin{tabular}{|c|c|c|c|c|c|c|c|}
\hline \multirow{2}{*}{$\begin{array}{c}\text { Motivational } \\
\text { Perception }\end{array}$} & \multicolumn{2}{|c|}{ Low } & \multicolumn{2}{c|}{ Moderate } & \multicolumn{2}{c|}{ High } & \multirow{2}{*}{ P-value } \\
\cline { 2 - 7 } & $\mathrm{f}$ & $\%$ & $\mathrm{f}$ & $\%$ & $\mathrm{f}$ & $\%$ & \\
\hline About TPG & 2 & 5 & 16 & 40 & 22 & 55 & .50 \\
\hline About HTPS & 3 & 7.5 & 8 & 20 & 29 & 72.5 & .80 \\
\hline
\end{tabular}

As seen in Table 3, the majority of participants had propounded that they were highly motivated on TPG and HTPS. Moreover, P-values of Chi-square analysis regarding the gender variable were greater than the critical significance level of .05 . It might be interpreted that there was no significant difference between the male and female participants' motivational perceptions on TPG and HTPS.

However, there was a difference in the number of the participants who rated themselves as moderately and highly motivated on TPG and HTPS. 29 of them were highly motivated on HTPS, while 22 of them were highly motivated on TPG. 8 of them rated themselves as moderately motivated on HTPS while 16 of them rated themselves as moderately motivated on TPG. This difference might suggest the presence of certain special issues and that their personal opinions/attitudes related to their subject area may affect their motivation on HTPS in a positive manner. In addition, the high rate of self-efficacy beliefs on the subject-specific competencies might also be the reason for their high level of motivation on HTPS. 
When the findings of the first and second sub-question were examined comparatively, there was a correlation between the self-efficacy and motivational perceptions of the participants. For TPG, 16 of the highly motivated 22 participants perceived themselves sufficiently adequate, 4 of them perceived themselves partially adequate and the other 2 perceived themselves inadequate for majority of the items of questionnaire. Besides this, 12 of the moderately motivated 16 participants perceived themselves partially adequate and the other 4 perceived themselves sufficiently adequate on majority of the items about TPG. Furthermore, for HTPS, 24 of the 29 highly motivated participants perceived themselves sufficiently adequate and the other 5 perceived themselves partially adequate on majority of the items. Apart of that, 5 of the moderately motivated 8 participants perceived themselves partially adequate, 2 of them perceived themselves sufficiently adequate and the other 1 perceived him/herself inadequate on majority of the items about HTPS. Both on TPG and HTPS, 5 low motivated participants perceived themselves inadequate in both generic and subject specific competencies. These findings were the sign of the relationship between the self-efficacy and motivational perceptions of the participants. Most of the highly motivated participants perceived themselves sufficiently adequate, most of the moderately motivated participants perceived themselves partially adequate and all of the low motivated participants perceived themselves inadequate on teacher competencies. At the same time, there were some exceptions. Some of the participants who perceived themselves partially adequate and inadequate generally on TPG and HTPS had high motivational perceptions. Moreover, some other participants who perceived themselves sufficiently adequate had moderate motivational levels. This showed that, factors other than the self-efficacy beliefs may influence the motivational perceptions of participants. To identify the reasons for their motivational perception, the participants were also asked about factors that motivate or demotivate them.

\subsection{Factors that Affect the Motivations of Pre-service History Teachers on TPG and HTPS}

After determining the motivational perception of participants, the next sub-question aimed to identify the reasons that motivate or demotivate them on TPG and HTPS. The motivating factors were exhibited in Table 4.
Table 4. The Factors which Motivate Pre-service History Teachers about TPG and HTPS

\begin{tabular}{|c|c|c|c|}
\hline & Motivating Factors & $\mathrm{f}$ & $\%$ \\
\hline \multirow{6}{*}{$\begin{array}{l}\text { About } \\
\text { TPG }\end{array}$} & Satisfaction of teaching the young people & 21 & 52.5 \\
\hline & $\begin{array}{l}\text { Feeling a sense of contribution towards } \\
\text { society }\end{array}$ & 12 & 30 \\
\hline & The role of teacher in knowledge transfer & 9 & 22.5 \\
\hline & $\begin{array}{l}\text { High esteem of the teaching profession in } \\
\text { society }\end{array}$ & 3 & 7.5 \\
\hline & Dynamism of teaching profession & 1 & 2.5 \\
\hline & Continuity of teaching profession & 1 & 2.5 \\
\hline \multirow{5}{*}{$\begin{array}{l}\text { About } \\
\text { HTPS }\end{array}$} & $\begin{array}{l}\text { Values that the history teaching would } \\
\text { inculcate in students }\end{array}$ & 16 & 40 \\
\hline & Continuous passion for history as a subject & 15 & 37.5 \\
\hline & The function/importance of knowing history & 13 & 32.5 \\
\hline & Personal competency on content knowledge & 6 & 15 \\
\hline & Past history teachers (as good models) & 3 & 7.5 \\
\hline
\end{tabular}

When the pre-service history teachers were asked about the factors that motivate them on TPG, intrinsic factors like "satisfaction obtained from teaching young people" (52.5\%), "feeling a sense of contribution towards society" (30\%) and "transferring knowledge to young people" $(22.5 \%)$ were the frequently mentioned factors. Participant 5 mentioned the satisfaction of teaching as "The feeling of achievement that came from teaching young people, helping their development and providing changes in their lives, is the most important motivational factor for me". About feeling a sense of contribution towards society, Participant 23 commented that "Teaching does not only bring benefits to individuals. It is a part of the whole. Teaching individuals means being bringing benefits for the whole society in which the individuals live in. This alone is enough reason for me to choose this profession." Participant 38 also identified knowledge transfer as a factor of motivation, giving a response saying that "Today, people have a need to equip themselves with various kinds of knowledge to adapt and keep up with the modern life. The teacher is one of the key people that provide people with this necessary knowledge. While we can obtain information by using different sources, is it as accurate and reliable as what the teachers provide?" 
On HTPS, participants frequently took into account of the intrinsic factors. "Values that the history teaching would inculcate in students" was the most mentioned (40\%) factor. Participant 18 said that "... the history teaching profession is very effective in encouraging the peaceful approach to the new generation, in a time where there are a lot of wars in the world". The participants "continuous passion for history as a subject" was one other effective motivating factor (37.5\%). Participant 21 mentioned that "History is my most favorite subject since childhood and history courses were the ones that I had been the most successful in. Hence, I am also very enthusiastic about the history teaching profession. My preference to teach history did not surprise anybody. I did not want to teach any other subject. "Function/importance of knowing history" was one other frequently (32.5\%) identified factor. An example can be seen in Participant 8's response, "the people who do not know his/her past will not have a role or be successful in shaping the future. History is a subject area that has great importance and this motivates me to teach the subject."

The factors which demotivate the participants on TPG and HTPS were shown in Table 5.

Table 5. The Factors which Demotivate Pre-service History Teachers about TPG and HTPS

\begin{tabular}{|c|c|c|c|}
\hline \multicolumn{2}{|r|}{ Demotivating Factors } & $\mathrm{f}$ & $\%$ \\
\hline \multirow{9}{*}{ About TPG } & $\begin{array}{l}\text { Public Personnel Selection Examination } \\
\text { (PPSE) }\end{array}$ & 15 & 37.5 \\
\hline & $\begin{array}{l}\text { Trivialization of teaching profession by } \\
\text { the educational system and policies }\end{array}$ & 10 & 25 \\
\hline & $\begin{array}{l}\text { Lack of freedom for teachers in } \\
\text { performing teaching }\end{array}$ & 4 & 10 \\
\hline & $\begin{array}{l}\text { Negative attitudes of students towards } \\
\text { teachers }\end{array}$ & 4 & 10 \\
\hline & $\begin{array}{l}\text { Security problems of teachers in various } \\
\text { parts of the country }\end{array}$ & 3 & 7.5 \\
\hline & $\begin{array}{l}\text { Low esteem of the teaching profession in } \\
\text { society }\end{array}$ & 3 & 7.5 \\
\hline & Low motivated in-service teachers & 3 & 7.5 \\
\hline & Low salaries & 2 & 5 \\
\hline & Inadequate school facilities & 2 & 5 \\
\hline \multirow{6}{*}{ About HTPS } & $\begin{array}{l}\text { Limited number of history teacher } \\
\text { appointments }\end{array}$ & 13 & 32.5 \\
\hline & $\begin{array}{l}\text { Lack of importance given to the history } \\
\text { courses in the education system }\end{array}$ & 9 & 22.5 \\
\hline & $\begin{array}{l}\text { History teaching was being exploited for } \\
\text { political aims }\end{array}$ & 7 & 17.5 \\
\hline & $\begin{array}{l}\text { Students' lack of interest towards history } \\
\text { courses }\end{array}$ & 6 & 15 \\
\hline & Feeling of inadequacy in history teaching & 5 & 12.5 \\
\hline & $\begin{array}{l}\text { Approaches of teachers in participants' } \\
\text { teacher training programs }\end{array}$ & 3 & 7.5 \\
\hline
\end{tabular}

As described in Table 5, most of the factors identified to have reduced their motivation on TPG and HTPS were the extrinsic factors.

One of the frequently mentioned demotivating factors for TPG was the "Public Personnel Selection Examination (PPSE)" that participants had to pass in order to be appointed as a teacher $(37.5 \%)$. With regards to this, Participant 15 commented that "The main reason that reduces my motivation for the teaching profession is the PPSE. We are trained for the teaching profession for 5 years but it not certain if I am able to become a teacher. We have to pass such a difficult exam in order to actually join the teaching profession". "Trivialization of the teaching profession by the educational system and policies" (25\%) was one other frequently mentioned factor that demotivated the participants. The opinion of Participant 40 highlights an example "I'm educated to become a teacher in this teacher training institution but due to changes in the educational system, others who were trained in the faculty of arts and sciences can also become a teacher just by completing only one year of pedagogy education course. What then is the point of my education specialized for teaching profession?" Other extrinsically demotivating factors for TPG included the potential in-service problems they would find themselves facing.

When asked about the factors demotivating them for HTPS, the majority of participants responded with extrinsic factors. Many of them (32.5\%) had emphasized on "limited number of history teacher appointments". With regards to this point, Participant 7 commented that "In Turkey, the number of appointments for history teachers are very low compared to the other subject fields. Only one or two of my friends who graduated from this program were appointed in past few years. This is the one factor demotivating me. Sometimes, I wish I had preferred another field". "Lack of importance given to the history courses in the education system" was one other frequently mentioned $(22.5 \%)$ demotivating factor on HTPS. Participant 22 commented with a statement that highlighted this factor, "there were only a few hours per week allocated to history lessons for the secondary education. This depicts the value placed on history as a subject in our educational system." In addition, the participants identified other extrinsic factors that demotivated them for HTPS. The only intrinsic demotivating factor $(12.5 \%)$ identified for HTPS was the feeling of inadequacy in the knowledge of the field education.

\subsection{The Relationship between Pre-service History Teachers' Self-efficacy Beliefs and Motivations on TPG and HTPS}

After the self-efficacy and motivational perceptions of participants were identified, the results related to the motivating and demotivating factors were analyzed to determine if there was a relationship between the self-efficacy beliefs and motivations of pre-service history teachers' on TPG and HTPS.

When the participants were asked about their motivating and demotivating factors, they had mentioned their feelings of adequacy or inadequacy in a direct form only to a slight extent. On HTPS, only 6 participants $(15 \%)$ identified their "personal competency on content knowledge" as the factor that motivated themselves and 5 participants $(12.5 \%)$ mentioned "the feeling of inadequacy in history teaching" as 
the reason for demotivation. However, the existence of a relationship between the participants' self-efficacy beliefs and motivations on TPG cannot be ruled out. When the self-efficacy and motivational perceptions of the participants were compared, it was seen that these were mostly relevant with some exceptions.

When asked about the factors that motivated them on TPG, they had mostly responded with personal attitudes about the teaching profession, such as the satisfaction of teaching young people, the importance of teachers for society and knowledge transfer. This may be related to their adequacy beliefs that they had expressed for generic teacher sub-competencies such as understanding, believing, valuing, guiding students, as well as for personal/professional values.

Furthermore, the most frequently mentioned motivating factors for HTPS were the importance of history teaching in teaching students about certain values, continuous passion for history and the function/importance of knowing history. Similarly, it may be associated with their positive self-efficacy beliefs in subject-specific sub-competencies related to the attitudes and values about the history subject and HTPS.

In contrast, for the demotivating factors about TPG and HTPS, the participants had mostly identified extrinsic factors like the PPSE, problems associated with teacher appointments and issues stemming from the educational system. Negative expectations regarding their teaching opportunities and the stakeholders for their in-service period were also mentioned frequently. It can be interpreted that factors other than self-efficacy beliefs were in the foreground of the demotivating perception that of pre-service history teachers hold for TPG and HTPS.

In summary, though not frequently mentioned, self-efficacy belief is a factor that has been directly identified by some participants $(27.5 \%$ in total $)$ as their motivating or demotivating factor for HTPS. At the same time, the sub-competencies for which they perceive themselves as adequate was coherent with the intrinsic factors that motivated them for TPG and HTPS. However, they were demotivated mostly due to extrinsic factors that were not related directly to their self-efficacy beliefs. To summarize, it can be said that there is a correlation between the self-efficacy beliefs and the motivations of pre-service history teachers on the teaching profession to a certain extent.

\section{Results and Discussion}

According to the results of the first sub-question of this research study, the majority of the pre-service history teachers had generally high self-efficacy beliefs, for both generic teacher competencies and subject-specific competencies for history teachers. This finding seems to agree with the results of research studies by Külekçi [66] who had researched on self-efficacy perceptions of pre-service English teachers, as well as the results of studies by Kahramanoğlu and Ay [67] who had studied the self-efficacy beliefs of pre-service primary education teachers. In the research, similar with the results of the researches of Külekçi [68], Saracaloğlu and Dinçer [69] and in contrast to the findings of Yeşilyurt [70], self-efficacy perceptions of the male and female participants were not significantly different.

This research study has found out there is quite a number of pre-service history teachers who perceived themselves as partially adequate for certain generic teacher sub-competencies. The participants had generally felt themselves to be partially adequate, especially in the areas of the "teaching and learning process", "monitoring and evaluation of learning and development", as well as "knowledge of curriculum and content". In this context, the results are parallel to the research of Önen and Muşlu Kaygisiz [71] who stated that the pre-service science teachers had not felt themselves adequate for some areas, such as pedagogy knowledge, lesson planning and teaching practices, while showing a high adequacy belief for other competencies. On the contrary, the results of this present research shows a contradiction with the research of Özer and Gelen [72] who stated that the pre-service teachers from all branches in their study had perceived themselves highly adequate for all generic teacher competencies.

On another point explored by this study, the rate of the participants who felt themselves sufficiently adequate for subject-specific competencies for history teachers was shown to be higher than their self-ratings for generic teacher competencies. The only 4 sub-competencies they felt partially adequate in were under the main competency of "knowledge of field education". Although their self-efficacy beliefs were generally high, the sub-competencies on which the majority of the participants perceived themselves partially adequate showed that generic teacher competencies and subject-specific competencies were not sufficiently taken into account and utilized in history teacher training institutions. Courses and practical opportunities were not sufficient in ensuring that prospective teachers felt themselves to be sufficiently adequate on some of the competencies.

Findings of the second sub-question showed that the motivational perceptions of the pre-service history teachers on TPG and HTPS were generally high. This is similar to the results of research studies by Akbaba [73], as well as Zehir Topkaya and Uztosun [74]. Besides this, it was also identified that the participants' motivation on HTPS (72.5\%) was higher than their motivation on TPG $(55 \%)$. It can be interpreted that features and characteristics unique to their subject area as well as their opinions/attitudes about the subject area that were identified by the second sub-question brought them higher motivation for HTPS. The gender variable was not significantly effective on the motivational perceptions of the participants unlike the findings of the 
researches of Saracaloğlu and Dinçer [75], and Zehir Topkaya and Uztosun [76]. Moreover, although there was a relevance between the self-efficacy and motivational perceptions of the participants, there were also some exceptions. This showed that, factors other than the self-efficacy beliefs may be effective on the motivational perceptions of participants. The factors motivating and demotivating the pre-service history teachers on TPG and HTPS were then examined in the third sub-question.

The satisfaction of teaching was the most identified motivational factor for TPG. This is similar to the study by Reid and Caudwell [77].The other most frequently mentioned factor was the feeling of a sense of contribution to society, a point that was also stated in the research by Hillmann [78] and Kyriacou, Hultgren and Stephens [79]. These factors related to the intrinsic values of teaching and social utility were also shown to be effective on the motivation of participants, as mentioned in the studies by Öztürk Akar [80] and Zehir Topkaya and Uztosun [81]. Furthermore, the demotivating factors for TPG that were identified by pre-service history teachers were found to be parallel to that of results from the studies by Başaran and Dedeoğlu Orhun [82], and Çeliköz [83].These factors included negative expectations related to the in-service period, PPSE, educational policies and policy makers, as well as the approaches of some stakeholders of the teaching profession.

The factors motivating the participants on HTPS were discussed in terms of the second sub-question's findings, where the number of participants highly motivated for HTPS was higher than that for TPG. Participants mostly mentioned the "values that the history teaching would inculcate in students" and "importance/function of history knowledge for people" as motivating factors for HTPS. These results are in agreement with the research study by Kyriacou, Hultgren and Stephens [84] who had explored the reasons motivating student teachers (in England and Norway) to become secondary school teachers. They identified that the importance placed by pre-service teachers on their subjects was a very effective factor for their motivation.

In this study, their consistent passion for the subject area since their early days was the other frequent motivating factor identified for some participants. This agrees to the findings by Virta [85] who mentioned that history was a domain that pre-service history teachers had identified as an area of passion since early on independent from formal school education. In addition, Virta [86] identified that the models adopted during early school years had a significantly strong influence on their attitudes towards teaching. Similarly, in this study, some of the participants had also mentioned their own previous history teachers (good models) as a motivating factor.

Lastly, in terms of the relationship between the self-efficacy and motivation, the analysis of the findings displayed a correlation but only to a certain extent. Sub-competencies on which they perceive themselves as adequate were coherent with the intrinsic factors (related to values and attitudes of participants) which motivated them for both TPG and HTPS. Moreover, the "personal competency on content knowledge" was identified as a motivating factor and "the feeling of inadequacy in history teaching" was identified as a demotivating factor directly related to the self-efficacy beliefs of participants on the HTPS. These findings support the study by Bandura [87] and Zimmerman [88] who highlighted the correlation between self-efficacy and motivation. In addition to this, in this study, it was shown that participants were demotivated mostly due to the extrinsic factors which were not connected directly with their self-efficacy beliefs. In this respect, the findings support the studies of Akbaba [89], Demirtaş, Cömert and Özer [90], Saracaloğlu and Dinçer [91], and Zehir Topkaya and Uztosun [92], where a moderate level of relationship between the self-efficacy and motivation was identified.

\section{Implications and Suggestions}

According to the findings of this study, there are some implications and suggestions to be made, with regards to pre-service process for increasing the pre-service teachers' self-efficacy beliefs and motivation on TPG and HTPS.

In Turkey, there is no framework deciding whether the "generic" and "subject-specific competencies" are taken into account and practiced in teacher training institutions, or to what extent they should be utilized. The quality of teacher training institutions can be improved comprehensively by audits carried out to ensure that the teacher candidates are better equipped with these competencies.

Pedagogy courses in teacher training institutions are generally taught by teachers from the department of educational sciences and not by field educators. The teachers in their own department teach about the content knowledge in general. Hence, the teacher candidates have to bridge the gap between pedagogy and content knowledge on their own. This may lead to their beliefs of inadequacy on the participants' knowledge of field education. Thus, courses at the teacher training institutions could taught by field educators in a way that better integrates pedagogy education and content knowledge, rather than treating the two as separate independent subjects.

According to the results, the PPSE that teacher candidates have to pass in order to gain appointment was the most demotivating factor that pre-service history teachers held towards TPG. The criteria for entering the teaching profession should not be decided based only one examination. Moreover, the participants had also identified the appointment shortages as the most demotivating factor for HTPS. In Turkey, the appointments for teachers are more problematic for some subjects for which the supply of teacher exceeds the demand. History is one of such subjects. This is also influenced by the fact that art and science faculty graduates could also be appointed as a teacher after only one 
year pedagogy education. This leads to a higher teacher supply in the fields of secondary education and the pre-service teachers in these specialized teaching programs felt that their education was not worth as much. Hence, the policies concerning teacher appointments should be reviewed in light of this.

As the demotivating factors for TPG, the negative in-service expectations were identified by the participants frequently. To eliminate them, opportunities for personal and professional development for teachers should be increased and better managed. In addition, teachers should give more freedom from curriculum restrictions and time shortages for their practicing activities should be addressed. Teachers can also be allowed to be more active in the development of educational policies and processes, such as for the curriculum development process. The number of teaching practice courses in schools can be increased, allowing more interaction between teacher candidates and in-service teachers, during their pre-service period. This may help to reduce some of the impact of the demotivating factors, when they actually join the profession during the in-service period, as they would have gained prior experience through the teaching practice courses.

In Turkey, as like in many other countries, history education was manipulated by the politicians because of its role in growing persona grata. Curriculums and textbooks were shaped according to political agendas. This is another factor that demotivates pre-service teachers on HTPS. Hence, history education should be kept separate from political agendas.

The negative attitude of students towards history courses is another demotivating factor for the participants. To address this, the weekly course hours for history may be increased to allow more time for the effectively teaching of the history curriculum. Through these measures, students may also be guided and encouraged to develop a more positive attitude towards the subject.

\section{REFERENCES}

[1] Council of the European Union, Education \& Training 2010 Work Program, Online available from http://www.consilium.europa.eu/uedocs/cms data/docs/press data/en/educ/111471.pdf

[2] J. M. Cooper, A. Alvarado. Preparation, Recruitment and Retention of Teachers: Education Policy Series, UNESCO, Paris, 2006.

[3] OECD (The Organisation for Economic Co-operation and Development). Teachers Matter: Attracting, Developing and Retaining Effective Teachers, 2005, Online available from https://www.oecd.org/edu/school/34990905.pdf

[4] M. Tschannen-Moran, A. Woolfolk Hoy. Teacher efficacy: Capturing an elusive construct, Teaching and Teacher Education, 17, 783-805, 2001.
[5] Bandura. Self-efficacy. In V. S. Ramachaudran (Ed.) Encyclopedia of Human Behavior (pp. 71-81), Academic Press, New York, 1994.

[6] R.M. Ryan, E. L.Deci. Intrinsic and extrinsic motivations: Classic definitions and new directions, Contemporary Educational Psychology, 25, 54-67, 2000.

[7] P. W. Richardson, H. M. G. Watt. Why people choose teaching as a career: An expectancy-value approach to understanding teacher motivation. In P. W. Richardson, S. A. Karabenick, H. M. G. Watt (Eds.), Teacher Motivation: Theory and Practice (pp. 3-19), Routledge, New York, 2014.

[8] D. H. Schunk. Self-efficacy and academic motivation, Educational Psychologist, 26, 207-231, 1991.

[9] A. Bandura. Self-efficacy: Toward a unifying theory of behavioral change. Psychological Review, 84(2), 191-215, 1977.

[10] D. Pendergast, S. Garvis, J. Keogh. Pre-service student-teacher self-efficacy beliefs: An insight into the making of teachers, Australian Journal of Teacher Education, 36(12), 46-58, 2011.

[11] M. Tschannen-Moran, A. Woolfolk Hoy. Teacher efficacy: Capturing an elusive construct, Teaching and Teacher Education, 17, 783-805, 2001.

[12] J. M. Cooper, A. Alvarado. Preparation, Recruitment and Retention of Teachers: Education Policy Series, UNESCO, Paris, 2006.

[13] OECD (The Organization for Economic Co-operation and Development). Teachers Matter: Attracting, Developing and Retaining Effective Teachers, 2005, Online available from https://www.oecd.org/edu/school/34990905.pdf

[14] J. M. Cooper, A. Alvarado. Preparation, Recruitment and Retention of Teachers: Education Policy Series, UNESCO, Paris, 2006.

[15] P. E. Goldberg, K. M. Proctor. Teacher Voices: A Survey on Teacher Recruitment and Retention, Scholastic Inc. and The Council of Chief State School Officers (CCSSO), Washington, DC, 2000.

[16] C. M. Guarino, L. Santibanez, G. A. Daley. Teacher recruitment and retention: A review of the recent empirical literature, Review of Educational Research, 76, 173-208. 2006.

[17] S. Loeb, J. Myung. Economic approaches to teacher recruitment and retention. In B. McGaw, P. Peterson, E. Baker (Eds.), International Encyclopedia of Education(pp.473-480), 2010.

[18] C. Alemdağ, E. Öncü, A. K. Yılmaz. Beden eğitimi öğretmeni adaylarının akademik motivasyon ve akademik öz-yeterlikleri. Spor Bilimleri Dergisi-Hacettepe Journal of Sport Sciences, 25(1), 23-35, 2014.

[19] H. Ateş, A. Saylan. Investigation of pre-service science teachers' academic self-efficacy and academic motivation toward biology, International Journal of Higher Education, 4(3), 90-103, 2015.

[20] G. Külekçi. A study on pre-service English teachers' self-efficacy beliefs depending on some variables, International Online Journal of Educational Sciences,3(1), 245-260, 2011. 
[21] C. Meinhardt, T. Rabe, O. Krey. Pre-service teachers' self-efficacy beliefs for teaching physics. In L. Avraamidou, M. Michelini (Eds.), ESERA e- book Strand 13: Pre-service science teacher education (pp. 244-250), 2013.

[22] F. Önen, G. Muşlu Kaygısız. Prospective science teachers' self-efficacy beliefs about teaching science between 6-8 terms and the opinions on these beliefs, Educational Sciences: Theory and Practice, 13(4), 2435-2453, 2013.

[23] N. Akkuzu, H. Akçay. Examination of the self-efficacy beliefs of prospective chemistry teachers in terms of different variables (The sample of Dokuz Eylül University), Educational Sciences: Theory \& Practice, 12(3), 2208-2216, 2012.

[24] C.M. Aurah, T. J.McConnell. Comparative study on pre-service science teachers' self-efficacy beliefs of teaching in Kenya and the United States of America; USA, American Journal of Educational Research, 2(4), 233-239, 2014.

[25] H. Demirtaş, M. Cömert, N. Özer. Öğretmen adaylarının öz-yeterlik inançları ve öğretmenlik mesleğine ilişkin tutumları. Education and Science, 36 (159), 96-111, 2011.

[26] G. Külekçi. A study on pre-service English teachers' self-efficacy beliefs depending on some variables, International Online Journal of Educational Sciences,3(1), 245-260, 2011

[27] D. Pendergast, S. Garvis, J. Keogh. Pre-service student-teacher self-efficacy beliefs: An insight into the making of teachers, Australian Journal of Teacher Education, 36(12), 46-58, 2011.

[28] A.E. Woolfolk, W. K. Hoy. Prospective teachers' sense of efficacy and beliefs about control, Journal of Educational Psychology, 82(1), 81-91, 1990.

[29] A. Woolfolk Hoy, R. Burke Spero. Changes in teacher efficacy during the early years of teaching: A comparison of four measures, Teaching and Teacher Education, 21, 343-356, 2005

[30] M. Başaran, B. Dedeoğlu Orhun. Öğretmen adaylarının mesleğe ilişkin motivasyonlarını etkileyen faktörler. İnönü Üniversitesi Eğitim Fakültesi Dergisi, 14(3), 129-151, 2013

[31] N. Çeliköz. Basic factors that affect general academic motivation levels of candidate preschool teachers. Procedia Social and Behavioral Sciences, 1, 1357-1365, 2009.

[32] H. Demirtaş, M. Cömert, N. Özer. Öğretmen adaylarının öz-yeterlik inançları ve öğretmenlik mesleğine ilişkin tutumları. Education and Science, 36 (159), 96-111, 2011

[33] R. M. Klassen, S. Al-Dhafrib,W. Hannoka, S. M.Bettsa. Investigating pre-service teacher motivation across cultures using the teachers' ten statements test, Teaching and Teacher Education, 27(3), 579-588, 2011.

[34] M., K. Spear. Gould, B. Lee. Who would be A Teacher? A Review of Factors Motivating and Demotivating Prospective and Practicing Teachers, National Foundation for Educational Research, Slough, 2000. Online available from https://www.nfer.ac.uk/publications/91003/91003.pdf

[35] E. Zehir Topkaya, M.S. Uztosun. Choosing teaching as a career: Motivations of pre-service English teachers in Turkey, Journal of Language Teaching and Research, 3 (1), 126-134, 2012.
[36] K. Yüce, E. Y. Şahin, Ö. Koçer, F. Kana. Motivations for choosing teaching as a career: A perspective of pre-service teachers from a Turkish context, Asia Pacific Educational Review, 14, 295-306, 2013.

[37] B. Akbaba. The attitudes of pre-service social studies teachers' towards teaching profession and their self-efficacy about using instruction materials. Mevlana International Journal of Education (MIJE), 3(2), 157-169, 2013.

[38] C. Alemdağ, E. Öncü, A. K. Yılmaz. Beden eğitimi öğretmeni adaylarının akademik motivasyon ve akademik öz-yeterlikleri. Spor Bilimleri Dergisi-Hacettepe Journal of Sport Sciences, 25(1), 23-35, 2014.

[39] H. Ateş, A. Saylan. Investigation of pre-service science teachers' academic self-efficacy and academic motivation toward biology, International Journal of Higher Education, 4(3), 90-103, 2015.

[40] H. Demirtaş, M. Cömert, N. Özer. Öğretmen adaylarının öz-yeterlik inançları ve öğretmenlik mesleğine ilişkin tutumları. Education and Science, 36 (159), 96-111, 2011.

[41] H. Bembenutty. Pre-service teachers' motivational beliefs and self-regulated learning. Paper presented at the annual meeting of the American Educational Research Association, Chicago, 2007.

[42] S. Saracaloğlu, B. Dinçer. A study on correlation between self-efficacy and academic motivation of prospective teacher, Procedia Social and Behavioral Science, 1, 320-325, 2009.

[43] MNEGDTT (Ministry of National Education General Directorate of Teacher Training), Generic Teacher Competencies, 2006, Online available from http://otmg.meb. gov.tr/belgeler/otmg/Generic_Teacher_Competencies.pdf

[44] MNEGDTT (Ministry of National Education General Directorate of Teacher Training), Generic Teacher Competencies, 2006, Online available from http://otmg.meb.gov.tr/belgeler/otmg/Generic Teacher_Com petencies.pdf

[45] MNEGDTT (Ministry of National Education General Directorate of Teacher Training), Generic Teacher Competencies, 2006, Online available from http://otmg.meb.gov.tr/belgeler/otmg/Generic_Teacher_Com petencies.pdf

[46] Ü. Candeğer. Tarih öğretmeni özel alan yeterliklerinin hazırlanması. Turkish History Education Journal, 4(1), 177-194, 2015.

[47] MNEGDTT (Ministry of National Education General Directorate of Teacher Training), Tarih Öğretmeni Özel Alan Yeterlikleri, 2011, Online available from http://otmg.meb.gov.tr/alan_tarih_ortaogretim.html.

[48] MNEGDTT (Ministry of National Education General Directorate of Teacher Training), Tarih Öğretmeni Özel Alan Yeterlikleri, 2011, Online available from http://otmg.meb.gov.tr/alan tarih ortaogretim.html.

[49] F J. Fowler, Cosenza, J. C. Writing effective survey questions. In E. D. De Leeuw, J. J. Hox , D. A. Dillman (Eds.), The International Handbook of Survey Methodology (pp. 136-160), Lawrence Erlbaum, Mahwah, NJ, 2008.

[50] J.J. Hox, De Leeuw, E.D., Dillman, D.A. 2008. The Cornerstones of Survey, In E. D. De Leeuw, J. J. Hox , D. A. 
Dillman (Eds.), The International Handbook of Survey Methodology (pp.1-18), Lawrence Erlbaum, Mahwah, NJ, 2008.

[51] J. W. Creswell. Research Design: Qualitative, Quantitative and Mix Methods Approaches, Sage, California, 2003.

[52] J. W. Creswell. Research Design: Qualitative, Quantitative and Mix Methods Approaches, Sage, California, 2003.

[53] L. M. Given (Ed.). The SAGE Encyclopedia of Qualitative Research Methods, Sage, California, 2008.

[54] A. Yıldırım, H. Şimşek. Sosyal Bilimlerde Nitel AraştırmaYöntemleri. Seçkin, Ankara, 2006.

[55] Ş. Büyüköztürk, E. Kılıç Çakmak, Ö. E. Akgün, Ş. Karadeniz, F. Demirel. Bilimsel Araştırma Teknikleri, Pegem, Ankara. 2008 .

[56] C.M. Aurah, T. J.McConnell. Comparative study on pre-service science teachers' self-efficacy beliefs of teaching in Kenya and the United States of America; USA, American Journal of Educational Research, 2(4), 233-239, 2014.

[57] C.H. Denham, J.J. Michael. Teacher sense of efficacy: A definition of the construct and a model for further research, Educational Research Quarterly, 5, 39-63, 1981.

[58] D. Pendergast, S. Garvis, J. Keogh. Pre-service student-teacher self-efficacy beliefs: An insight into the making of teachers, Australian Journal of Teacher Education, 36(12), 46-58, 2011.

[59] L. A. Smolleck, A. M. Mongan. Changes in pre-service teachers' self-efficacy: From science methods to student teaching, Journal of Educational and Developmental Psychology, 1(1), 133-145, 2011.

[60] H. Kim, Y. Cho. Pre-service teachers' motivation, teacher efficacy, and expectation of reality shock, Asia-pacific Journal of Teacher Education, 42(1), 67-81, 2014.

[61] J. J. Watters, I. S. Ginns. Developing motivation to teach elementary science: Effect of collaborative and authentic learning practices in pre-service education, Journal of Science Teacher Education, 11(4), 277-313, 2000.

[62] S. Kvale. Interviews: An Introduction to Qualitative Research Interviewing, Sage, London, 1996.

[63] M. Q. Patton. Qualitative Evaluation and Research Methods, Sage, California, 1990.

[64] N. Karasar. Bilimsel Araştırma Yöntemi. Nobel Yayın Dağıtım, Ankara, 2007.

[65] H.J. Rubin, I.S. Rubin. Qualitative Interviewing: The Art of Hearing Data, Sage, London, 1995.

[66] G. Külekçi. A study on pre-service English teachers' self-efficacy beliefs depending on some variables, International Online Journal of Educational Sciences,3(1), 245-260, 2011

[67] R. Kahramanoğlu, Y. Ay. Sınıf öğretmeni adaylarının özel alan yeterlik algılarının çeşitli değişkenler açısından analizi, International Journal of Turkish Literature Culture Education, 2(2), 285-301, 2013.

[68] G. Külekçi. A study on pre-service English teachers' self-efficacy beliefs depending on some variables, International Online Journal of Educational Sciences,3(1), 245-260, 2011.

[69] S. Saracaloğlu, B. Dinçer. A study on correlation between self-efficacy and academic motivation of prospective teacher, Procedia Social and Behavioral Science, 1, 320-325, 2009.

[70] Yeşilyurt, E. Öğretmen adaylarının öğretmen özyeterlik algiları, Elektronik Sosyal Bilimler Dergisi, 12 (45), 88-104, 2013.

[71] F. Önen, G. Muşlu Kaygısız. Prospective science teachers' self-efficacy beliefs about teaching science between 6-8 terms and the opinions on these beliefs, Educational Sciences: Theory and Practice, 13(4), 2435-2453, 2013.

[72] B. Özer, İ. Gelen. Öğretmenlik mesleği genel yeterliklerine sahip olma düzeyleri hakkında öğretmen adayları ve öğretmenlerin görüşlerinin değerlendirilmesi, Mustafa Kemal University Journal of Social Sciences Institute, 5(9), 39-55, 2008 .

[73] B. Akbaba. The attitudes of pre-service social studies teachers' towards teaching profession and their self-efficacy about using instruction materials. Mevlana International Journal of Education (MIJE), 3(2), 157-169, 2013.

[74] E. Zehir Topkaya, M.S. Uztosun. Choosing teaching as a career: Motivations of pre-service English teachers in Turkey, Journal of Language Teaching and Research, 3 (1), 126-134, 2012 .

[75] S. Saracaloğlu, B. Dinçer. A study on correlation between self-efficacy and academic motivation of prospective teacher, Procedia Social and Behavioral Science, 1, 320-325, 2009.

[76] E. Zehir Topkaya, M.S. Uztosun. Choosing teaching as a career: Motivations of pre-service English teachers in Turkey, Journal of Language Teaching and Research, 3 (1), 126-134, 2012.

[77] I. Reid, J. Caudwell. Why did secondary PGCE students choose teaching as a career, Research in Education, 58, 46, 1997.

[78] J. Hillmann. Undergraduate perceptions of teaching as a career. In National Commission on Education: Insights into Education and Training, Paul Hamlyn Foundation, Heinemann, London, 1994.

[79] C. Kyriacou, A. Hultgren, P. Stephens. Student teachers' motivation to become a secondary school teacher in England and Norway, Teacher Development, 3(3), 373-381, 1999.

[80] E. Özturk Akar. Motivations of Turkish pre-service teachers to choose teaching as a career, Australian Journal of Teacher Education, 37(10), 66-84, 2012.

[81] E. Zehir Topkaya, M.S. Uztosun. Choosing teaching as a career: Motivations of pre-service English teachers in Turkey, Journal of Language Teaching and Research, 3 (1), 126-134, 2012 .

[82] M. Başaran, B. Dedeoğlu Orhun. Öğretmen adaylarının mesleğe ilişkin motivasyonlarını etkileyen faktörler. İnönü Üniversitesi Eğitim Fakültesi Dergisi, 14(3), 129-151, 2013.

[83] N. Çeliköz. Basic factors that affect general academic motivation levels of candidate preschool teachers. Procedia Social and Behavioral Sciences, 1, 1357-1365, 2009. 
[84] C. Kyriacou, A. Hultgren, P. Stephens. Student teachers' motivation to become a secondary school teacher in England and Norway, Teacher Development, 3(3), 373-381, 1999.

[85] A. Virta. Becoming a history teacher: Observations on the beliefs and growth of student teachers', Teaching and Teacher Education, 18 (6), 687-698, 2002.

[86] A. Virta. Becoming a history teacher: Observations on the beliefs and growth of student teachers', Teaching and Teacher Education, 18 (6), 687-698, 2002.

[87] A. Bandura. Self-efficacy: Toward a unifying theory of behavioral change. Psychological Review, 84(2), 191-215, 1977.

[88] B.J. Zimmerman. Self-efficacy: An essential motive to learn. Contemporary Educational Psychology, 25, 82-91, 2000.
[89] B. Akbaba. The attitudes of pre-service social studies teachers' towards teaching profession and their self-efficacy about using instruction materials. Mevlana International Journal of Education (MIJE), 3(2), 157-169, 2013.

[90] H. Demirtaş, M. Cömert, N. Özer. Öğretmen adaylarının öz-yeterlik inançları ve öğretmenlik mesleğine ilișkin tutumlar1. Education and Science, 36 (159), 96-111, 2011.

[91] S. Saracaloğlu, B. Dinçer. A study on correlation between self-efficacy and academic motivation of prospective teacher, Procedia Social and Behavioral Science, 1, 320-325, 2009.

[92] E. Zehir Topkaya, M.S. Uztosun. Choosing teaching as a career: Motivations of pre-service English teachers in Turkey, Journal of Language Teaching and Research, 3 (1), 126-134, 2012. 